\title{
ADMINISTRATIVE-TERRITORIAL REFORM IN UKRAINE: NORMATIVE-LEGAL ASPECT OF DECENTRALIZATION REFORM IN UKRAINE
}

Olena I. Lisova Postgraduate student, Lecturer of the Department of General Subjects, Faculty of Law, Dnipropetrovsk State University of Internal Affairs 26 Gagarina Ave., Dnipro, Ukraine, 49005 https://orcid.org/0000-0002-5433-9523 lisoval@i.ua

Maxim 0. Shevyakov Senior lecturer at the Department of Administrative Law, Procedure and Administrative Activity, Dnipropetrovsk State University of Internal Affairs, 26 Gagarina Ave., Dnipro, Ukraine, 49005 https://orcid.org/0000-0002-6443-9544 mshevyakov1212@gmail.com

Olena O. Orlova $\mathrm{PhD}$ in Law, Associate Professor, Associate Professor of the Department of General Subjects, Faculty of Law, Dnipropetrovsk State University of Internal Affairs, 26 Gagarina Ave., Dnipro, Ukraine, 49005 https://orcid.org/0000-0001-7707-4612

elenaorlova@ukr.net

Abstract. The need for effective, capable self-government inevitably faces the need to change the spatial organization of local governments. In turn, the territorial organization of executive bodies also turned out to be far from optimal. In Ukraine, there have been discussions for many years about the reorganization (reform) of the entire system of public power in the country. But they have mainly always concerned the redistribution of powers in the power triangle at the national level: President - Parliament - Government. Since independence, changes have taken place here many times. However, despite the changes taking place in this redistribution at the national level, people living in specific towns and villages continue to face the same problems.

To date, not clear enough mechanisms have been implemented to form effective local self-government and territorial organization of government to ensure the provision of high quality and affordable public services, meet the interests of citizens in all spheres of life in the territory, harmonize the interests of the state and local communities, establishing cooperation between the authorities and local governments. 
Currently, the second stage of decentralization in Ukraine continues in 2020-2021. The Cabinet of Ministers of Ukraine has identified the need for further reform process, introduction of decentralization in Ukraine as one of the priorities in the state, which will continue the development of local self-government, territorial communities and in general will enable the growth of Ukraine's economic indicators.

In this regard, this article is aimed at studying the state of administrative-territorial reform in Ukraine, as well as outlining areas for improving the legal aspect of decentralization reform in Ukraine, as for further development of the legal framework, to continue the reform requires a number of important laws.

Keywords: administrative reform, decentralization, public authorities, local governments, territorial communities.

\section{INTRODUCTION}

The structure of the system, the balance of power and the order of functioning of local governments and public authorities in Ukraine contain elements of potential conflict, as it is not fully regulated and enshrined in law. The solution of this problem becomes possible under the condition of reorganization, distribution of all power functions and power powers between executive bodies and local self-government bodies, which is not considered possible without decentralization and optimization of administrative-territorial structure in Ukraine by forming territorial communities. sufficient powers to enable communities to address local issues on their own to meet their needs.

In Ukraine, such a process of formation of a new system of administration, the process of reform and reorganization has already begun and continues today. Legislative support for a radical change in the system of local government, local self-government and their territorial basis at all levels began to take shape in 2014.

In accordance with the Order № 333-r of the Cabinet of Ministers of Ukraine „On approval of the Concept of reforming local self-government and territorial organization of power in Ukraine" (2014), hereinafter referred to as „Concept”, set the start and vector of direction for the reform process and the mechanism of functioning of local self-government bodies and their powers.

The above Concept sets out the main problems, from the point of view of public authorities, that need to be addressed.

Thus, in accordance with the issues enshrined in the above Concept, Ukraine laid down the constitutional principles of local self-government, ratified the European Charter of Local Self-Government (1985), adopted a number of basic legal acts that create the legal and financial basis for local self-government.

However, since the adoption of the Constitution of Ukraine (1996) and basic regulations on local self-government, the development of local self-government has actually been carried out only at the level of territorial communities of cities of regional significance, as the vast majority of territorial communities unable to perform all the powers of local governments. 


\section{MATERIALS AND METHODS}

Achieving the goal of the study necessitated the development of 13 regulations and notifications on the government portal governing decentralization in Ukraine, as well as the use of general scientific (analysis and synthesis, methods of empirical research) and special methods (systemic and structural-functional).

\section{RESULTS AND DISCUSSION}

Problems of functioning and reform of local self-government in Ukraine are studied by scientists, scientists - representatives of many sciences, first of all, they are specialists in the field of public administration and local self-government. The most famous scientific works are the publications of V. Andriyash, V. Antonenko, T. Astanova, E. Afonin, M. Baimuratov, O. Batalov, I. Bubenko, O. Chepel, V. Butenko, V. Zablotsky, L. Dem'yanenko, V. Kuybida, V. Malyukova, M. Pukhtinsky, Y. Sharov and others.

Despite numerous studies and existing scientific achievements of domestic scientists in the disclosure of this issue, there are still issues in the relationship between public authorities and local governments, in the processes of division of powers, decentralization, further implementation of the European Charter of Local Self-Government.

For example, V.V. Zablotsky (2015) the blocked analytical state and perspective transformations of administrative reform determine that a characteristic feature of the current state of Ukraine is its European integration direction of development, which provides, ensuring all, a significant transformation of the public administration system, a key element of which is self-government. The problem of compliance of the local selfgovernment system of Ukraine with the requirements of the European Charter is covered in the recommendations and resolutions of the Parliamentary Assembly of the Council of Europe (Resolution № 1179 of 1999) and the Congress of Local and Regional Authorities of Europe (Recommendation № 48 and Resolution № 68 of 1998).

As noted by Olga Chepel (2019), analyzing the international experience, namely the peculiarities of decentralization processes in Ukraine, Poland and Latvia, and other European states, such unitary states as Denmark, Norway, Sweden, Poland, the Czech Republic, Estonia, France, shows that the transfer of significant powers from state authorities to local selfgovernment bodies, so that those bodies that are closest to the people have as much power as possible, ensuring change of local self-government, respectively, elimination of artificial barriers (excessive permits, instances, excessive control of the center) for business and entrepreneurial activity, creation of transparent investment climate and opportunities of able (money, resources) communities to effectively address issues of population importance and development their territories.

\section{CONCLUSIONS}

In Ukraine, it was no longer possible to postpone decentralization due to a number of negative factors: the imperfection of the existing structure of the administrative system; 
uncertainty of the status of many administrative-territorial units and division into categories; significant difference in population, area and other parameters; inconsistency of the administrative-territorial division of Ukraine operating in the EU country; low efficiency of local self-government bodies; insufficient tax base for budget financing of regional and local development; lack of mechanisms of influence on the production and social spheres; imperfection of the system of legal relations within the administrative units of local selfgovernment bodies and local state administrations; polarization of interests of the center and regions; lack of conditions for investment and development of local business. Thus, it was necessary to determine the territorial basis of local governments and executive authorities on the basis of the current situation, development forecasts, experience of leading countries; principles of separation of powers between local governments at different levels and between local governments and the executive; calculate the required amount of resources at each level; to make the organizer of the new self-government accountable to the voters and the state; to ensure the limitation of the possibilities of the state bureaucracy's influence on the socio-economic life; use the self-organization of society as a mechanism of socio-economic development; addressing the issue of openness and transparency in the administration of local taxes and fees by local governments; creation of favorable legal conditions for involvement of inhabitants of territorial communities in acceptance of administrative decisions on places, development of forms of local democracy; creation and administration of the Unified State Register of Acts of Local Self-Government Bodies within the framework of the implementation of the new budget program «E-Government in the Sphere of Development of Communities and Territories of Ukraine»; creation and administration of the State Register of Powers of Local Self-Government Bodies within the framework of the implementation of the new budget program «E-Government in the Sphere of Development of Communities and Territories of Ukraine».

To further develop the legal framework, to continue the reform it is necessary to adopt a number of important laws:

- On the principles of administrative-territorial organization of Ukraine. Within the framework of the current Constitution, it determines the principles on which the administrative-territorial structure of Ukraine should be based, types of settlements, system of administrative-territorial units, powers of state authorities and local selfgovernment bodies on administrative-territorial organization, formation, liquidation, establishment and change. borders of administrative units and settlements, maintaining the State Register of administrative-territorial units and settlements of Ukraine.

- About service in local governments (to state in new edition).

Ensure equal access to service in local governments, increase the prestige of service in local self-government, motivation of local employees to develop communities and their own development;

- Regarding state supervision over the legality of decisions of local self-government bodies;

- About the local referendum;

- Update of laws on local self-government, on local state administrations, etc. 


\section{DISCUSSIONS}

The system of local self-government today does not meet the needs of society. The functioning of local governments in most local communities does not provide the creation and maintenance of a favorable living environment necessary for comprehensive human development, self-realization, protection of human rights, providing local governments, their institutions and organizations of high quality and affordable administrative, social and other services. in the relevant territories (hereinafter - public services).

The implementation of permanent financial support through the district budgets of small territorial communities using the system of equalization subsidies is burdensome for the state budget and hinders the development of small towns and large settlements. The system of territorial organization of power also needs to be improved in order to increase the efficiency of social development management in the respective territory.

Preservation of disproportion of the administrative-territorial system as the basis for the existence of irrational territorial organization of power (lack of an integral territory of the administrative-territorial unit of the basic level, the presence of the territorial community of a village, settlement, city in another territorial community or in another administrativeterritorial unit city) leads to a conflict of competence both between local governments and between local governments and local executive bodies.

As stated in the Concept (2004), the implementation of structural reforms will achieve a sustainable economic effect provided that the priorities and stages of these reforms are harmonized with the reform of local self-government and territorial organization of power.

To implement the provisions of the Concept and the objectives of the Action Plan, it was necessary first of all to make appropriate changes to the Constitution of Ukraine, as well as to form a package of new legislation. Amendments to the Constitution were primarily intended to address the formation of executive bodies of regional and district councils, reorganization of local state administrations into control and supervisory bodies, to give a clear definition of the administrative-territorial unit - the community. Through the efforts of domestic specialists, practitioners, scientists, and experts, the draft amendments to the Constitution were developed and submitted for wide public discussion. The proposed changes were supported by the public and praised by the Venice Commission. Unfortunately, political circumstances did not allow the Verkhovna Rada of Ukraine to adopt the amendments to the Constitution on decentralization submitted by the President of Ukraine. Therefore, in 2014, the Government launched a reform within the current Constitution.

It should be emphasized that the main results of the Concept (2004) should be: strengthening the legal, organizational and material capacity of territorial communities, local governments, conducting their activities in compliance with the principles and provisions of the European Charter of Local Self-Government, introduction of a mechanism for local state administrations and the population to exercise control over the provision of public services by local self-government bodies, territorial bodies of central executive bodies; introduction of standards (norms) of quality of public services provided to the population by local selfgovernment bodies of basic and regional level, criteria of quality assessment; creation of favorable legal conditions for the widest possible involvement of the population in management decisions, as well as the development of forms of direct democracy; formation 
of an effective territorial system of local self-government bodies and local executive bodies to ensure sustainable socio-economic development of the respective administrativeterritorial units; formation of united territorial communities, capable of resolving issues of local significance independently or through local self-government bodies; socio-economic development of territorial communities and regions; stimulation of economic development of territories as a result of improvement of mechanisms of influence of local governments on definition of priorities of local economic development; defining clear boundaries of each administrative-territorial unit, ensuring the ubiquity of the jurisdiction of local governments in the territory of the respective administrative-territorial unit and preventing the presence within the community of other administrative-territorial units of the same level; formation of executive bodies of regional and district councils; change of the status of local state administrations from bodies of general competence to control and supervisory bodies in the system of executive power with the function of coordinating the activities of territorial bodies of central executive bodies in the respective territory; ensuring the distribution of powers between local and regional self-government bodies, local state administrations and territorial bodies of central executive bodies.

According to Article 5 of the Basic Law of Ukraine - the Constitution of Ukraine (1996), the people exercise power directly and through public authorities and local governments. In Ukraine, local self-government is recognized and guaranteed (Article 7 of the Constitution of Ukraine). Public authorities and local governments, their officials are obliged to act only on the basis, within the powers and in the manner prescribed by the Constitution and laws of Ukraine (Part 2 of Article 19 of the Constitution of Ukraine).

Article 2 of the Law of Ukraine «On Local Self-Government» (1997) defines the concept of „local self-government in Ukraine”, namely: it is a state-guaranteed right and real capacity of the territorial community - villagers or voluntary association of residents of several villages, settlements, cities - independently or under the responsibility of bodies and officials of local self-government to resolve issues of local importance within the Constitution and laws of Ukraine. Local self-government is exercised by territorial communities of villages, settlements, cities both directly and through village, settlement, city councils and their executive bodies, as well as through district and regional councils, which represent the common interests of territorial communities of villages, settlements and cities.

Reform of local governments and territorial organization of power in Ukraine (decentralization), aimed at creating conditions for the formation of effective and responsible local government, the creation of a basic subject of local government - a capable territorial community.

Thus, taking into account the above needs, there is a need to form a basic basic regulatory package of documents that would ensure a clear and smooth, without legal conflicts, the functioning of the new system.

The first steps were to amend the Budget (2010) and Tax (2010) codes of Ukraine. As a result, there was financial decentralization, namely local budgets increased.

The next step in decentralization in Ukraine was the adoption by the Verkhovna Rada of Ukraine of the Law of Ukraine «On Voluntary Association of Territorial Communities» (2015). This Law regulates the relations arising in the process of voluntary association of 
territorial communities of villages, settlements, cities, as well as voluntary accession to the united territorial communities. Due to the norms of this Law, neighboring city, settlement, and village councils may unite into one community, which will have one joint local selfgovernment body.

The Basic Law in Ukraine - Article 140 of the Constitution of Ukraine (1996) states: local self-government is the right of a territorial community - villagers or voluntary association of villagers of several villages, settlements and cities - to decide on local issues within the Constitution and laws of Ukraine. Local self-government is carried out by the territorial community in the manner prescribed by law, both directly and through local governments: village, town, city councils and their executive bodies. District self-government bodies representing the common interests of territorial communities of villages, settlements and cities are district and regional councils. The issue of organization of district administration in cities belongs to the competence of city councils. Village, settlement, city councils may allow on the initiative of residents to create house, street, neighborhood and other bodies of self-organization of the population and give them part of their own competence, finances, property.

The Law of Ukraine «On Local Self-Government in Ukraine» (1997) defines the concept of a territorial community, namely: a territorial community is residents united by permanent residence within a village, settlement, city, which are independent administrative-territorial units, or voluntary association of residents of several villages, settlements, cities with a single administrative center.

Voluntary association of territorial communities of villages, settlements, cities is carried out in accordance with the following conditions in accordance with Article 4 of the Law of Ukraine «On Voluntary Association of Territorial Communities» (2015): 1) within the united territorial community there can be no other territorial community, which has its own representative body of local self-government; 2) the territory of the united territorial community must be inseparable, the boundaries of the united territorial community are determined by the external boundaries of the jurisdiction of the councils of the united territorial communities; 3) historical, natural, ethnic, cultural and other factors influencing the socio-economic development of the united territorial community are taken into account when making decisions on voluntary association of territorial communities; 4) the quality and availability of public services provided in the united territorial community may not be lower than before the union.

From the date of taking office of the village, settlement, city council elected by the united territorial community, in the manner prescribed by this Law, the reorganization of the relevant legal entities - village, settlement, city councils, elected by the united territorial communities and located outside the administrative center of the united territorial community, by joining them to a legal entity - village, settlement, city council, located in the administrative center of the united territorial community. Upon completion of the reorganization, the relevant legal entities - village, settlement, city councils shall be terminated in the manner prescribed by this Law. Legal entity - village, settlement, city council, located in the administrative center of the united territorial community, is the successor of the rights and obligations of all legal entities - village, settlement, city councils elected by the united territorial communities 
from the date of acquisition powers of the village, settlement, city council, elected by the united territorial community. The name of the representative body of local self-government of the united territorial community as a legal entity consists of a part that is derived from the proper name of the settlement, determined by its administrative center, in the form of an adjective and the corresponding general name of the representative body of local selfgovernment (village, settlement, city council).

The state provides informational, educational, organizational, methodological and financial support for voluntary association of territorial communities and joining united territorial communities. Methodological support for voluntary association of territorial communities and joining united territorial communities, determination of the scope and form of support is provided by the central executive body, which ensures the formation and implementation of state policy in the field of territorial organization of power, administrative-territorial organization, local self-government development.

In addition, the Resolution of the Cabinet of Ministers of Ukraine № 214 (2015) approved the Methodology for the formation of affluent territorial communities. This Methodology determines the procedure for developing a long-term plan for the formation of territories of communities in the region (hereinafter referred to as „long-term plan”) and the conditions for the formation of project-capable territorial communities. This Methodology enshrines the basic concept, namely: «Project-capable territorial community (hereinafter referred to as the able-bodied territorial community) - territorial communities of villages, settlements, cities, which as a result of voluntary association (voluntary joining of the united territorial community) are able to ensure the appropriate level of provision independently or through relevant local governments public services, in particular in the field of education, culture, health care, social protection, housing and communal services, taking into account human resources, financial support and infrastructure development of the relevant administrativeterritorial unit.».

The next component of the legal framework governing the functioning of local governments, decentralization and development of territorial communities is the Law of Ukraine „On Cooperation of Territorial Communities" (2014), which defines the organizational and legal framework for cooperation of territorial communities, principles, forms, mechanisms cooperation, its stimulation, financing and control. Article 1 of this Law stipulates that "cooperation of territorial communities" (hereinafter referred to as "cooperation") is a relationship between two or more territorial communities carried out on a contractual basis in the forms specified by this Law in order to ensure socio-economic, cultural development of territories, improving the quality of services to the population on the basis of common interests and goals, effective implementation by local governments of the powers defined by lawSuch cooperation is based on the principles of: 1) legality; 2) voluntariness; 3) mutual benefit; 4) transparency and openness; 5) equality of participants; 6) mutual responsibility of the subjects of cooperation for its results. The subjects of cooperation are territorial communities of villages, settlements, cities. Territorial communities cooperate through village, settlement and city councils. Cooperation is carried out in the form of: 1) delegation to one of the subjects of cooperation by other subjects of cooperation of performance of one or several tasks with transfer to it of corresponding resources; 2) implementation 
of joint projects, which provides for the coordination of the activities of the subjects of cooperation and their accumulation for a certain period of resources for the purpose of joint implementation of relevant measures; 3 ) joint financing (maintenance) by the subjects of cooperation of enterprises, institutions and organizations of communal form of ownership - infrastructure facilities; 4) formation of joint utilities, institutions and organizations - joint infrastructure facilities; 5) formation by the subjects of cooperation of a joint governing body for the joint implementation of the powers specified by law. At the state level, cooperation is stimulated by: 1provision of subventions to local budgets of subjects of cooperation in priority spheres of state policy; 2) transfer of objects of state property to the communal property of the subjects of cooperation; 3) methodological, organizational and other support for the activities of the subjects of cooperation. The state stimulates cooperation if: the ability of the subjects of cooperation to ensure the implementation of the statutory powers is strengthened; additional resources, including financial, are involved in cooperation; cooperation is carried out by more than three subjects of cooperation; broad public participation in cooperation is ensured.

The Law «On Cooperation of Territorial Communities» (2015) created a mechanism for solving common problems of communities: waste disposal and recycling, development of common infrastructure, etc.

Summing up the first part of the reform, we can highlight the following key results of decentralization reform: In Ukraine, the decentralization process began in 2014 with the adoption of the Concept of Local Government Reform and Territorial Organization in Ukraine (2014), laws of Ukraine «On Cooperation of Territorial Communities» (2014), On Voluntary Association of Territorial Communities» (2015) and amendments to the Budget (2010) and Tax (2010) Codes - on financial decentralization. This process made it possible to form, in accordance with the provisions of the European Charter of Local Self-Government (1985), a significant, effective and capable institution of local self-government at the basic level united territorial communities. According to the government portal (2021), 670 OTGs were formed during the 6 years of the reform, in which 4882 communities voluntarily joined. Of these, 936 OTGs held the first local elections. The government has approved long-term plans for the formation of communities in 24 oblasts, which cover $100 \%$ of the oblast's territory. The area of formed OTG is almost $47 \%$ of the total area of Ukraine. More than $70 \%$ of the population of Ukraine lives in OTGs and cities of regional significance. Therefore, with the amendments to the Tax and Budget Codes, from January 1, 2015, local governments received more funding to increase economic capacity. The united communities have acquired the powers and resources that cities of regional significance have, in particular - the transfer to the local budgets of OTG $60 \%$ of the personal income tax on their own powers. In addition, revenues from taxes remain entirely on the ground: the single tax on the profits of enterprises and financial institutions of communal property and property tax (real estate, land, transport). In addition, OTGs have direct inter-budgetary relations with the state budget (before the reform only oblast and rayon budgets, budgets of cities of oblast significance had direct relations), they are provided with appropriate transfers (grants, educational and medical subventions, subventions for development) community infrastructure, etc.). Legislative changes also gave local governments the right to approve local budgets regardless of the 
date of adoption of the law on the State Budget. Such improvements have already yielded the first noticeable results. Own revenues of local budgets from 2014 to 2019 increased by UAH 200 billion. (from UAH 68.6 billion to UAH 267 billion). It is a real tool for influencing the achievement of results and responsibility for the trust of communities. On January 23, 2019, the Cabinet of Ministers of Ukraine (2019) initiated the transition to a new stage of decentralization reform, which involves consolidating the successes and forming capable communities, changing the territorial structure at the district and community levels, clear delineation of powers and functions of control. development of forms of local democracy.

January 23, 2019 № 77-r The Cabinet of Ministers of Ukraine approved by the Order «Action Plan for the implementation of a new stage of reforming local self-government and territorial organization of power in Ukraine for 2019-2021» (2019), which sets the following main objectives: territorial basis for the activities of authorities at the level of communities and districts; transfer (decentralization) of powers of executive bodies to local self-government bodies and their delimitation on the principle of subsidiarity; creation of an adequate resource base for the exercise of the powers of local self-government bodies; formation of an effective system of service in local governments; development of forms of direct democracy: elections, referendums.

2020 has become a key year in the formation of a basic level of local self-government: most of the existing small local councils will unite, take over most of the powers, use resources properly and be accountable for their actions or inactions to the people and the state. This will create a solid foundation for the next steps in local government reform, as well as accelerate reforms in health, education, culture, social services, energy efficiency and other sectors.

One of the main reasons for the new zoning is to prevent duplication of powers of district bodies and self-government bodies of newly created communities in one territory. The division into districts is based on the methodological recommendations of the Ministry of Development of Communities and Territories of Ukraine (Ministry of Regional Development), which is based on the standard of the European Union. Among the criteria for the formation of the district - location within one area, coverage «usually at least 150 thousand inhabitants, compactness and continuity of the territory». The center of the district was chosen in the following sequence: first - cities - regional centers, then - cities with a population of at least 50 thousand. The districts usually included communities located within a 60-kilometer zone of accessibility from the district center. If the community was equidistant from 2 or more district centers, it was included in the district whose district center was closer to the community administrative center.

According to the Blagodatne community of the Nikolaev area of the Pervomaisky area. (2020), January 1, 2021, all schools in Ukraine should become the property of communities. The key in the work of the district state administration after January 1, 2021 is social protection, state programs and coordination of various bodies of the SES, police, forestry. District councils will be a support for those institutions that communities will not be able to afford. It is a part of district hospitals, out-of-school educational establishments, children's and youth sports schools, orphanages, homes for elderly people. The key thing that the district loses after the transfer of power to the communities is money, namely $60 \%$ of the 
personal income tax (PIT), who live within the district. Instead of the district, they will go to the communities immediately. The district budget will now be largely replenished by utilities that remain on its balance sheet and subsidies from the state budget. The staffing problem that may arise for district employees is solved in such a way that most specialists will be able to find jobs in OTG staff and services, which will inherit most of the functions that the district government takes care of under the current model.

The second stage of decentralization in Ukraine is currently underway. According to the Minister of Community and Territorial Development Oleksiy Chernyshov, the decentralization reform will be completed in 2021 during a press conference dedicated to the 100 days of the government's work in Ukraine.

\section{CONCLUSIONS}

Given the above, the following conclusions can be drawn: in Ukraine it was no longer possible to postpone decentralization due to a number of negative factors: the imperfection of the existing structure of the administrative system; uncertainty of the status of many administrative-territorial units and division into categories; significant difference in population, area and other parameters; inconsistency of the administrative-territorial division of Ukraine with the current norms in the EU countries; low efficiency of local self-government bodies; insufficient tax base for budget financing of regional and local development; lack of mechanisms of influence on the production and social spheres; imperfection of the system of legal relations within the administrative units of local self-government bodies and local state administrations; polarization of interests of the center and regions; lack of conditions for investment and development of local business. Thus, it was necessary to determine the territorial basis of local governments and executive authorities on the basis of the current situation, development forecasts, experience of leading countries; principles of separation of powers between local governments at different levels and between local governments and the executive; calculate the required number of resources at each level; make local governments accountable to voters and the state; to ensure the limitation of the possibilities of the state bureaucracy's influence on the socio-economic life; use the self-organization of society as a mechanism of socio-economic development.

To further develop the legal framework, to continue the reform it is necessary to adopt a number of important laws:

- On the principles of administrative-territorial organization of Ukraine. Within the framework of the current Constitution, it determines the principles on which the administrative-territorial structure of Ukraine should be based, types of settlements, system of administrative-territorial units, powers of state authorities and local selfgovernment bodies on administrative-territorial organization, formation, liquidation, establishment and change. borders of administrative units and settlements, maintaining the State Register of administrative-territorial units and settlements of Ukraine.

- About service in local governments (to state in new edition). Ensure equal access to service in local governments, increase the prestige of service in local self-government, motivation of local employees to develop communities and their own development; 
- Regarding state supervision over the legality of decisions of local self-government bodies;

- About the local referendum;

- Update of laws on local self-government, on local state administrations, etc.

In 2021, the Constitution is expected to be amended to decentralize, which is needed to further advance the reform and complete it.

According to the Government, in order to further reform and obtain the expected results, it is necessary to form an effective local self-government and an optimal system of territorial organization of power on a new territorial basis by: consolidation of the reform of local self-government and territorial organization of power in Ukraine by making appropriate amendments to the Constitution of Ukraine; distribution of powers between local selfgovernment bodies and executive bodies, including the powers of territorial bodies of central executive bodies, their subdivisions, taking into account the principle of subsidiarity and the new territorial basis; introduction of a balanced budget model of revenues and expenditures of local governments to perform their own and delegated powers; reformatting of local state administrations in accordance with the new competence, the main powers of which will be to ensure law and order, respect for the rights and freedoms of citizens, implementation of state and regional programs, coordination (interaction) of territorial bodies of central executive bodies, administrative supervision of legality Local Government; development of forms of inter-municipal cooperation, in particular concerning creation and activity of city agglomerations; addressing the issue of openness and transparency in the administration of local taxes and fees by local governments; creation of favorable legal conditions for involvement of inhabitants of territorial communities in acceptance of administrative decisions on places, development of forms of local democracy; creation and administration of the Unified State Register of Acts of Local Self-Government Bodies within the framework of the implementation of the new budget program «E-Government in the Sphere of Development of Communities and Territories of Ukraine»; creation and administration of the State Register of Powers of Local Self-Government Bodies within the framework of the implementation of the new budget program «E-Government in the Sphere of Development of Communities and Territories of Ukraine».

\section{RECOMMENDATIONS}

The materials of the article can be used for further research of administrative-territorial reform in Ukraine, improvement of the legal framework and introduction of decentralization, as well as of practical value for all interested public authorities and concerned citizens

\section{REFERENCES}

Blagodatne community Mykolaiv region, Pervomaisky district. (2020). Zoning according to the new administrative-territorial system: what to expect? Retrieved from https://blagodatnenska-gromada.gov.ua/ news/1596444952/

Cabinet of Ministers of Ukraine. (2014). The concept of reforming local self-government and territorial organization of power in Ukraine. 
Cabinet of Ministers of Ukraine. (2019). Order № 77-r «On approval of the action plan for the implementation of a new stage of reforming local self-government and territorial organization of power in Ukraine for 2019-2021».

Chepel Olga. (2019). Reform of Municipal Authorities and Administrative-territorial Device: on the example of Ukraine, Poland and Latvia. Enterprise, statehood and law, № 5, 185-189. https://doi. org/10.32849/2663-5313/2019.5.34.

Council of Europe. (1985). European Charter of Local Self-Government.

Government portal. Decentralization reform. (2021) Retrieved from https://www.kmu.gov.ua/diyalnist/ reformi/efektivne-vryaduvannya/reforma-decentralizaciyi

Resolution of the Cabinet of Ministers of Ukraine (2015) № 214 «On the methodology of forming affluent territorial communities»

The second stage of decentralization in Ukraine 2019-2021. Retrieved from https://parkservis.kiev.ua/ news/drugyy-etap-decentralizaciyi-v-ukrayini-2019-2021-roky

The Verkhovna Rada of Ukraine. (1996). Constitution of Ukraine № 254k / 96-VR.

The Verkhovna Rada of Ukraine. (2010). Budget Code of Ukraine.

The Verkhovna Rada of Ukraine. (2010). Tax Code of Ukraine.

The Verkhovna Rada of Ukraine. (1997). Law of Ukraine «On Local Self-Government in Ukraine».

The Verkhovna Rada of Ukraine. (2014). Law of Ukraine «On Cooperation of Territorial Communities».

The Verkhovna Rada of Ukraine. (2015). Law of Ukraine «On Voluntary Association of Territorial Communities».

Zablotsky, V.V. (2015). Administrative reform: state and prospects of transformations. State management: perfect development, 7. Retrieved from http://www.dy.nayka.com.ua/?op=1\&z=868 